\title{
Control of clearing of milk line on the basis of technological innovations
}

\author{
Paliy A.
}

Candidate of Agricultural Sciences

Kharkiv National Technical University of Agriculture named after Petr Vasilenko

The purpose. To develop innovative technological approach to determination of quality of washing of milk line on the basis of application of effective means. Methods. Determination of quality of technological operation on washing of milk line after milking. Results. Technological approach is developed to determination of quality of clearing of milk line of milking plant which provides mark assessment of purity of realization of process of clearing at use of the device for determination of quality of washing of milk line. Conclusions. Use of this technological approach under production conditions will create preconditions of producing milk of high quality.

Key words: milk, milking plant, washing, milk line, quality of clearing, ball assessment.

Formulation of the problem. Farm activities currently happening in the dynamic development of the market economy, highly competitive, increasing complexity of production processes, while maintaining a certain limited resources. In these circumstances the main task is to observe the principles manufacturer customer satisfaction and continuous quality improvement.

Dairy cattle is a priority for agriculture in Ukraine. The transformation of dairy cattle in the prestigious, profitable and competitive industry can be achieved through the introduction of new innovative technologies [1, 2].

Analysis of factors which affect the quality of milk in terms of its production, shows that the main of them - contamination during the milking. It is the period of performance of technological operations fall in milk mechanical impurities, which are carriers of a large number of bacteria, and are getting into the milk rapidly develop, because there are favorable nutrient medium. Under these conditions much worse technological and sanitary properties of the product $[3,4]$. So to have a high sanitary quality milk, you as thoroughly clean milking equipment and milk before using it.

Therefore, the process control of cleaning are some of the most important technological operations, performance of which depends on the initial level of contamination of milk and, consequently, obtaining products of good quality.

Analysis of recent research and publications. We know that the content of microorganisms in milk depends on effective sanitary measures on a dairy farm at its reception: conditions of cows sanitary conditions of dairy equipment, milk cooling temperature, the time required to reach the desired temperature refrigeration and shelf life of milk on a dairy farm.

Currently, the global market competitiveness a priority factor in favor of its food quality and safety. Ukraine Competitiveness dairy industry as a whole can only be the case when adjusted production of high quality milk.

In view of the above, priority development of domestic dairy is the development and introduction of new innovative material and technical means and technologies that will provide the high quality products.

Research on the issue of getting high-grade milk on farms and industrial complexes devoted to the work of such scholars as Panin A.A. [5], Dehterev G.P., Kochetkova Y.A. [6], Zhmyrko A.M. [7] and others. But despite the success, the resulting research on the issue of obtaining adequate quality milk remains unsolved problem of ensuring control of technological operation to clean milking equipment and milk.

Given the above, we have developed an innovative technological approach for determining the quality of dairy washing line.

The purpose of research - to develop innovative technological approach to determining the quality of dairy washing lines through the use of effective tools.

Materials and methods of research. The study was conducted at milking unit, which consists of a metal frame of two parallel-access points of machines with input and output gate, actuated Pneumatic, vacuum wire made of plastic pipe with a nominal diameter of $110 \mathrm{~mm}$, mounted on a frame machines and 
plastic crosses, tees, angles and joints for connection of pipes among themselves, Milk made of stainless steel pipes with a diameter of $45 \mathrm{~mm}$ and connected to milk receiver indoors dairy, milking of electromounted control units and sensors of the milk flow, lines for washing of milk and manipulators milking Wash Solution, coupled with wash machine, located in the premises of the dairy, lines for washing the udder of cows with warm water using a sprinkler nozzles, milk receiver with milk pump AMC-6.

For visual determination of the quality of performance of technological operations dairy washing line after milking, cleaning quantitative importance of quality, studies were conducted in the same conditions suitable for matching and comparison.

Results. For a highly resistant and all dairy milk storage equipment and small inventory at the end of the production process to be sanitized. Dairy processing equipment includes the consistent implementation of the following operations: preliminary rinsing with warm water $\left(30 \pm 5^{\circ} \mathrm{C}\right)-$ remove the remnants of milk, circulating hot washing $\left(60 \pm 5^{\circ} \mathrm{C}\right)$ detergent - removed protein and fat film; disinfected to kill pathogenic organisms and reduce bacterial contamination; acid treatment to remove the "milk stone" and a final washing with tap water and detergent residues disinfectant solutions. When using detergent-disinfectants circulating washing with hot detergent solution and disinfect combine.

For rapid and reliable evaluation of the quality of the implementation of the above-mentioned process operations we have developed a device for determining the quality of dairy washing line (Fig. 1).
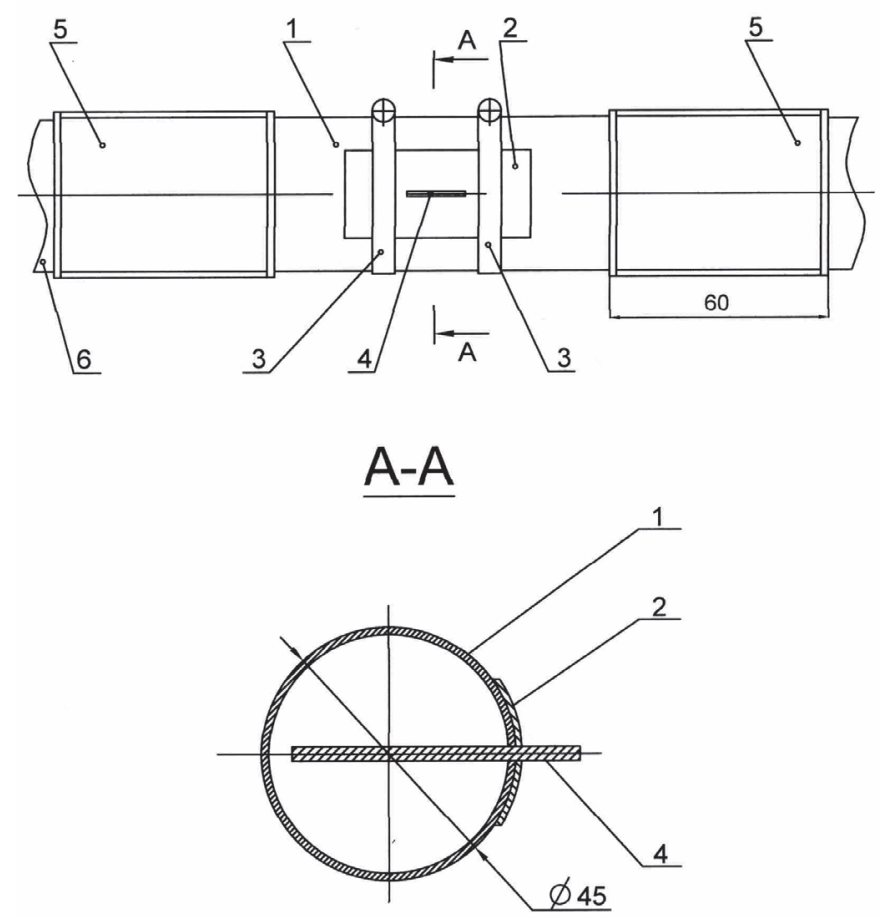

Figure $1-A$ device for determining the quality of washing breast line

The device consists of a pipe section 1, which has an opening, plug 2 clamps for fastening stopper 3, subject plate couplings 4 and 5 .

The device operates as follows: the milk straight section 6 via couplings secured area 5 tube 1. Hole 2 gag stopper with fixed therein subject plate 4 . At the end of milking machines, as well as during the maintenance substantive plate 4 is taken to determine the quality of washing and variable aperture gag stopper $2[8]$.

The method of determining the quality of dairy washing line for use developed device is as follows: defining transparency before milking clean plate and record the value. Then the plate is placed in wire milk so that the front portion of a $10 \mathrm{~d}$ (where $\mathrm{d}$ - diameter of milk) and after - a $5 \mathrm{~d}$ no local support hydraulic fluid leakage.

During the process they are milking pollution, and during the process washing - cleaning.

After the cleaning process removed the plates and determine their light transmission. The values are compared with the initial figure and determined in points $[9,10]$.

Interpretation of the data is shown in table 1. 


\section{The scoring soiled plates}

\begin{tabular}{|l|l|}
\hline Scores & $\begin{array}{l}\text { Decrease respect light permeability } \\
\text { initial value, \% }\end{array}$ \\
\hline I - well & $<10$ \\
\hline II - satisfactory & $11-19$ \\
\hline III - poor & $>20$ \\
\hline
\end{tabular}

Found that the reduction light permeability plate not more than $10 \%$ purity washing breast line estimated and score - well, decreasing by $11-19 \%$ - purity washing milk line is estimated in the second score - satisfactory, and the reduction light permeability plates over $20 \%$ purity lactic washing line estimated at third points - poor.

\section{Conclusions}

1. Proper quality milk on farms and industrial complexes such remains a problem, the solution of which is possible through the development of an effective way to remove different in nature from pollution wire milk internal surfaces of the available technology with the introduction of quality control of dairy washing lines.

2. To determine the efficiency of treating breast line milking machines developed technological approach determining the quality of washing milking 3 oh-point scale, the use of which in a production environment create conditions ensure that the highest quality milk.

\section{Prospects for further research}

The development of innovative technologies and technical means in dairy farming will create the conditions for increased productivity and prestige of labor in the agricultural sector, ensuring receiving high-quality products through quality forecasting receive milk.

\section{Bibliography}

1. Palij A.P. Tehnologichnij pidhid shhodo viznachennja chistoti promivannja molochnoï liniï doïl'nih ustanovok [Tekst] / A.P. Palij // Materiali VIII Vseukr. nauk.-praktik. konf. molodih vchenih "Suchasni dosjagnennja u tvarinnictvi ta ptahivnictvi". - Harkiv, 2014. - S. 51-52.

2. Bava L. Efficiency of cleaning procedure of milking equipment and bacterial quality of milk [Text] / L. Bava, M. Zucali, M. Brasca [and others] // Ital. J. Anim. Sci. - Vol. 8 (Suppl. 2). - 2009. - P. 387-389.

3. Palij A.P. Doslidzhennja procesu ochishhennja doïl'nih ustanovok riznogo tipu pislja doïnnja [Tekst] / A.P. Palij // Naukovo - tehnichnij bjuleten' 112. - Harkiv, 2014. - S. 109-114.

4. Ostapjuk M.P. Vdoskonalennja veterinarno-sanitarnogo kontrolju otrimannja moloka na fermah [Tekst] / M.P. Ostapjuk, V.V. Kasjanchuk // Nauk. visn. L'viv. derzh. akad. vet. medicini im. S. Z. Gzhic'kogo. - L'viv, 2011. - T. 13, № 4 (50), Ch. 4.: Vet. nauki. - S. 314-318.

5. Panin A.A. Kontrol' kachestva vnutrennej poverhnosti molokoprovoda doil'noj ustanovki [Tekst] / A.A. Panin // Izvestija OGAU. - 2011. - № 1 (29). - Orenburg. - S. 51-54.

6. Degtjarev G.P. Vlijanie tehnologicheskih parametrov na kachestvo promyvki doil'no-molochnogo oborudovanija [Tekst] / G.P. Degtjarev, Ju.A. Kochetkova // Sbornik nauchnyh trudov GNU VNIIMZh "Nauchno-tehnicheskij progress $\mathrm{v}$ zhivotnovodstve - resursosberezhenie na osnove sozdanija $\mathrm{i}$ primenenija innovacionnyh tehnologij i tehniki". - T. 18, Ch. 2. - Podol'sk, 2008. - S. 52-58.

7. Zhmyrko A.M. Kachestvo ochistki detalej molokoprovoda ot zagrjaznenij pri ego cirkuljacionnoj mojke [Tekst] / A.M. Zhmyrko // Sovershenstvovanie processov i tehnicheskih sredstv v APK. Zernograd, 2005. - Vyp. 6. - S. 62-65.

8. Pat. na korisnu model' № 91982 UA, MPK A01J7/00. Pristrij dlja viznachennja jakosti promivannja molochnoï liniï [Tekst] / A.P. Palij. - № u201401526; zajavl. 17.02.2014; opubl. 25.07.2014, Bjul. № 14 .

9. Pat. na korisnu model' № 76751 UA, MPK A01J7/00, A01J7/02. Sposib viznachennja jakosti promivannja molochnoï liniï [Tekst] / A.P. Palij, A.P. Palij, O.A. Naumenko. - № u201208821; zajavl. 17.07.2012; opubl. 10.01.2013, Bjul. № 1.

10. Svidoctvo pro reestraciju avtors'kogo prava na tvir № 60526 Innovacijni tehnologichni operaciï u zagal'nij sistemi otrimannja visokojakisnogo moloka [Tekst] / A.P. Palij. - data reestraciï 07.07.2015. 